\title{
The Impact of Teacher Values, Classroom Atmosphere, and Student-Teacher Relationship towards Student Attitude during Learning Process
}

\author{
Suyatno, Asih Mardati, Wantini, and Dholina Inang Pambudi \\ Universitas Ahmad Dahlan, Indonesia \\ Ganis Amurdawati \\ Universitas Negeri Semarang, Indonesia
}

\begin{abstract}
This study aimed to cover the various gaps from previous studies, which only focused on one factor. Furthermore, it measures the impact of three independent variables namely teacher values, classroom atmosphere, and student-teacher relationship towards student attitude. This is a quantitative study using hypothesis analysis with the respondents comprising of 72 teachers and 72 students from three junior high schools in Belitung regency. The data obtained was examined using the multivariate analysis. However, the result showed that amongst the three variables, only the classroom atmosphere provided a significant impact on student attitude. Based on the simultaneous testing of regression, the combination among $X_{1}$ and $X_{2}, X_{1}$ and $X_{3}$, as well as $X_{1}, X_{2}, X_{3}$ also provided an impact to their attitude. This finding needs further study capable of identifying factors which arises in the classroom atmosphere since it is the only factor that significantly impacts on student attitude. In addition, similar studies with a more significant number of respondents such as teachers or students also need to be conducted to determine why the outcome is different differs from previous studies.
\end{abstract}

Keywords: Teacher Values, Student-Teacher Relationship, Classroom Atmosphere, and Student Attitude.

\section{Introduction}

Academic achievements of students are dependent on several factors. However, student attitude towards the learning process is the most impactful factor at school, as those with a positive attitude tend to have a promising grade and vice versa (Papanastasiou, 2000; Nicolaidou \& Philippou, 2003; Bramlett \& Herron, 2009; Bakar et al., 2010; Mohd et al., 2011). Mager (Rivera \& Ganaden, 2001) stated that student attitude during learning process needs to be upgraded owing 
to some of the following reasons: 1) It will be directly related to achievement, as the better the attitude they possess, the more exceptional grade they probably obtain in the class. 2) Students with good attitude have a more significant probability of deepening and learning knowledge by themselves. 3) Attitude is often being communicated with other people, especially friends at the same age as it tends to affect their psychology of learning. Even though teachers play a big role towards in this, they have minor knowledge of factors related to the learning process. This is, therefore, the main reason why studies concerning student attitude need to be carried out.

However, some literature studies have been conducted on this topic. For instance, Ramirez (2005) focused on the environmental impact using internal and external factors. Values and motivation could be counted as internal factors (Adegboyega, 2018), while the study environment could be counted as an external factor. The method used by teachers (Adesoji, 2008) were personal experience, culture, famous figure, mass media, institution or organization, and emotional factor of each (Azwar, 2000). Zakaria et al. (2010) stated that a cooperative method of learning could develop student attitude as they tend to gain more confidence during the process, which made them succeed in solving given problems. This finding was considerably strengthened by Ifamuyiwa and Akinsola (2008).

This research is, however, different from previous studies, as it focused on the three factors, which are teacher values, student-teacher relationship, and classroom atmosphere. These were made utilized since they tend to be ignored by teachers in upgrading student attitude, especially in a classroom environment which is rarely examined in Indonesia (Tarmidi, 2006). There were no previous studies that measured the impact of this three-factor (teacher values, studentteacher relationship, and class room atmosphere ) towards student attitude as it is very important for teachers to identify factors that positively impact on student attitude.

\section{Research Questions}

The research questions of this research are as follows: 1) Is there an influence of teacher values on student attitude? 2) Is there an influence of classroom atmosphere on student attitude? 3) Is there an influence of student-teacher relationship on student attitude? 4) Is there a simultaneous influence of teacher values and classroom atmosphere on student attitude? 5) Is there a simultaneous influence of classroom atmosphere and student-teacher relationship on student attitude? 6) Is there a simultaneous influence of teacher values and studentteacher relationship on student attitude? 7) Is there a simultaneous influence of teacher values, classroom atmosphere, and student-teacher relationship on student attitude?

\section{Literature Review}

\subsection{Student a settled way of thinking or feeling about something}

It is an internal symptom that has affective dimension and tendency to react or respond to a specific object, positively or negatively (Walgito, 2003; Thohirin, 
2005; Syah, 2010). Bohner and Wanke (2002) stated that it is a summary of the evaluation from object thought by someone. Attitude is an important component of every aspect of people in pursuing success. It is categorized into agree and disagree, happy or unhappy, and like or dislike toward a specific object.

Slameto (2010) and Walgito (2003) stated that attitude is formed by three components, namely cognitive, effective, and behavior. The knowledge, perspective, and faith in which people give perspective towards a specific object are part of cognitive components. The feeling of like and dislike towards something is part of the affective components. Happiness is a positive feeling, while the opposite is unhappiness. Meanwhile, the conative feeling is the way people behave towards something. This shows the intensity of our behavior or acts towards something, and its size. Djaali (2009) stated that attitude towards the learning process affects students achievement.

\subsection{Factors affecting student attitude}

Mohammed and Waheed (2011) reported that there are three factors affecting student attitude towards the learning process namely: 1) factors related to the students such as achievement (Köğce et al, 2009), anxiety towards school subjects, self-conception and efficacy, extrinsic motivation (Tahar et al., 2010), and high school experiences (Klein, 2004), 2) factors related to learning process such as, teachers, teaching materials, the teacher's comprehension on the learning content/TCK, personality, learning topic in real life, student perception towards the learning process (Yilmaz et al., 2010), learning method (Papanastasiou, 2000), and receiving private tuition (Köğce et al., 2009) and 3) society and environment such as occupation of parents, education background and hopes of parents (Köğce et al., 2009). From the various factors affecting student attitude, this study focused on three variables, which was teacher values, student-teacher relationship, and classroom atmosphere.

\subsubsection{Teacher values}

Values are an emotional expression in fulfilling each need (Tirri, 2010). It is manifested into good deeds of moral principles. Lickona (2004) and Lockwood (2009)stated that values are concrete behavior and acts of moral used by people to determine their choices. It also plays an important role in educating society to be more democratic (Print, 2000). Sahin (2015) stated that values and culture are interconnected to build society. People continuously strive to absorb values in the society they are living in (Senturk \& Aktas, 2015).

Teachers always behave by considering values as supported by several studies (O'Sullivan, 2005), which showed that teachers taught and treated their students based on the values they possessed. This was further strengthened by Lovat (2007a) argued that teachers with specific values would give positive impacts during the learning process. Teachers and students were also demanded to express their values (Willemse et al., 2005).

Suyatno et al. (2019a) stated that the values possessed by teachers would affect their teaching style and treatment towards students. Those with positive experience based-values would treat their students using pedagogical principals, which created a good, comfortable, and pleasing learning process and positively 
impacted on their attitude. Suyatno et al. (2019b) also stated that teacher values also affected their professionalism as the higher the values, the more professional they became.

Based on the above explanation, below are the hypotheses of the study:

\section{Hypothesis 1:}

There was a positive and significant relation between teacher values and student attitude during the learning process.

\subsubsection{Classroom atmosphere}

The classroom atmosphere is one important factor affecting student attitude. Ezeife and Smith (2010) defined it as a condition during the learning process, which is emerged by the interaction between teachers and students, as well as amongst students (Zedan, 2010). Good classroom atmosphere is created by the good relationship between teachers and students which successfully creates an effective atmosphere (Patrício et al., 2015; Kutsyuruba et al., 2015; Liu et al., 2015; Scrimin et al., 2018). Baek \& Choi (2002) added that classroom atmosphere has different quality, such as warmth and support or stiffness and firmness. Moos divided it into three dimensions, which are, relationship, personal development, and maintenance and system change. Relationship dimension shows the alliance between students and teachers as well as amongst students. It also shows how they behave in the classroom. Personal development dimension shows individual growth and how it affects society, while maintenance and system change shows the regularity of society and the environment. These three dimensions were then developed into seven indicators and upgraded relation dimension into three indicators, which are student cohesiveness, teacher support, and involvement. Student cohesiveness focuses on how they assimilate, support, and help each other. Beside student cohesiveness, teacher support, and student involvement in the class activities are also included in this dimension. This atmosphere was portrayed by some indicators such as positive interaction between teachers and students, class management, and low rate of the critical and controlled act (from teachers) (Howes, 2000; NICHD Early Child Care Research Network [ECCRN], 2005).

Study related to the classroom atmosphere and its impact had been conducted several times, which indicated that there was a positive impact between the classroom atmosphere and student attitude. Good classroom atmosphere gives positive student attitude and keeps increasing by a better atmospheric condition (Limpo et al., 2013; Velegol \& Zappe, 2016). The study of Anderson et al. (2004) also showed that it was fully connected to student attitude, including participation, learning involvement, and assignment completion. It also increased the participation of learning and social competition among students (NICHD ECCRN, 2005; Wilson et al., 2007). The study conducted by Hamre and Pianta (2005), Wilson et al. (2007), Thomas et al. (2011), Bossér and Lindahl (2019), and Karpouza \& Emvalotis (2019) also had the same conclusion which showed positive and supportive relationships between students and teachers supported by personal development and conflict management. 


\section{Hypothesis 2:}

There is a positive and significant impact between the classroom atmosphere and student attitude.

\subsubsection{Student-teacher relationship}

The student-teacher relationship is an emotional and meaningful relationships as it enables a prolonged interactive period (Fraire et al., 2013., \& Longobardi et al., 2016). Many studies (Hamre \& Pianta, 2001; Quaglia et al., 2013; Settanni et al., 2015) showed that good relationship between teachers and students would provide an impact on the relationship among students. Furthermore, it could also contribute to their development, make them more adaptive, developed, and strengthens their academic performance.

Decker et al. (2007) and Klen \& Connel (2004) stated that teachers who maintained a good relationship with students would make them more independent, cooperative, and more involvement in the learning process. While, bad relationship between teachers and students led to passive (Jungert et al., 2016) and health problems (Lucas-Molina et al., 2015).

Spilt et al. (2012) explained that the affective relation between teachers and students had become a big consideration among researches in the past two decades. A positive relationship between teachers and students was believed to impact student involvement and achievement at school (Hughes et al., 2008; Walker \& Graham, 2019). Cumulative experience on the student-teacher relationship has a long-term impact on student achievement and development (Spilt et al., 2012).

Spilt et al. (2012) stated that the significant impact of a good relationship between teachers and students towards student achievement could be found in many previous studies (Hamre \& Pianta, 2001; Mercer \& DeRosier, 2008). This substantial impact could be found in both minor ethnicity and children with attitude and academic problems (Ladd \& Burgess, 2001; Hughes et al., 2008; Pianta et al., 2008).

Furthermore, Hamre and Pianta (2001) and Ladd and Dinella (2009) also stated that good relationship between teachers and students. Other studies (Ladd \& Burgess, 2001; Ladd et al., 2008) argued that the relation between teachers and students measured the capability of student adapting to the school environment. The positive relationship gave impact to their social interaction (Zins et al., 2000) and they could be tougher while dealing with every pressure (Jungert et al., 2016; Thomberg, et al., 2016).

The quality of the relationship between teachers and students became an important aspect for elementary school to adapt both in academic and social aspect in the future. Several studies (Hamre \& Pianta, 2001; Hamre et al., 2006; Pianta \& Stuhlman, 2004) reported that warm and supportive relationship between teachers and students positively impact to student achievement. Another study (Furrer \& Skinner, 2003; Gest et al., 2005) stated that students with a warm and supportive relationship with their teachers are more obedient and well behaved. 
Teacher support was also believed to rise their learning interest (Gest et al., 2005). Other Studies (Eisenberg et al., 2005) stated that the student-teacher relationship could control student interest and behavior. Negative relationship between teachers and students also would have a negative impact (Blair, 2002) while the supportive relationship between teachers and students could develop student ability of problem-solving, self-regulation, and effective interaction with other people (Pianta, 2006). Related to this, Espelage and Swearer (2003), Rodkin and Hodges (2003), Gini et al. (2015), Stuhlman and Pianta (2002), also Hughes and Im (2016) found that the quality of the relationship between teachers and students positively impacted on the students.

Based on the literature mentioned above reviews, the following hypotheses were made concerning students' attitude:

\section{Hypothesis 3:}

There was a simultaneous positive and significant impact between studentteacher relationship.

\section{Hypothesis 4:}

There was a simultaneous positive and significant impact between values and student-teacher relationship.

\section{Hypothesis 5:}

There was a simultaneous positive and significant impact between values and classroom atmosphere.

\section{Hypothesis 6:}

There was a simultaneous positive and significant impact between studentteacher relationship and classroom atmosphere.

\section{Hypothesis 7:}

There was a simultaneous positive and significant impact between values, student-teacher relationship, and classroom atmosphere.

\section{Research methods}

This is a quantitative study which utilized hypothesis testing to measure the impact of $X_{1}, X_{2}$, and $X_{3}$ towards $y$ both separately and simultaneously. The research design could be seen in Figure 1.

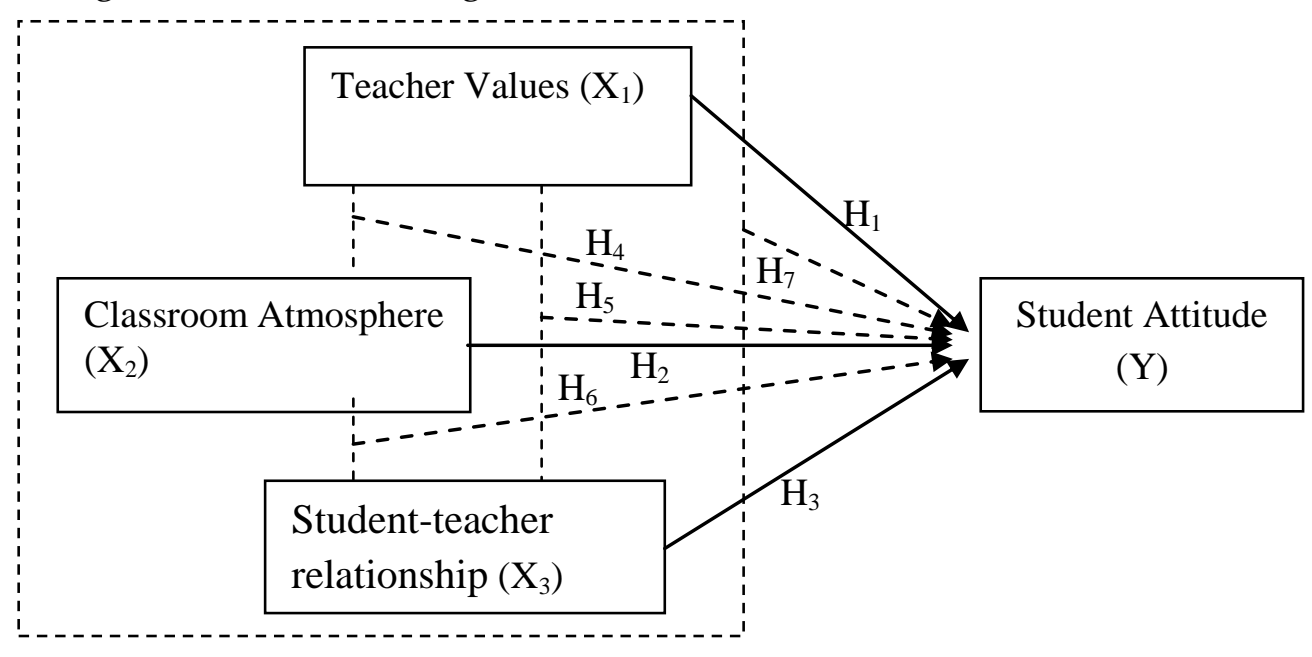

Figure 1. Research design 


\subsection{Participants}

The subjects of the study were three junior high schools in Belitung regency namely Tanjung Panjang 2 Junior High School (Grade 1) Tanjung Pandan 1 Junior High School (Grade 2), and Tanjung Pandan 1 PGRI Junior High School (Grade 3) respectively. A total of 72 students from the sample were assigned to fill the questionnaire on classroom atmosphere and student attitude, while 72 teachers were also assigned to fill the questionnaire on teacher values and student-teacher relationship. The demographic subject of the study could be seen in tables 1 and 2.

Table 1. Teacher Demography

\begin{tabular}{lll}
\hline Demographics & Total & Percent \\
\hline Gender & & \\
\hline Male & 25 & 34.7 \\
\hline Female & 47 & 65.3 \\
\hline Age (Years) & & \\
\hline $20-30$ & 14 & 19.5 \\
\hline $31-40$ & 35 & 48.6 \\
\hline $41-50$ & 16 & 22.2 \\
\hline $51-60$ & 7 & 9.7 \\
\hline Education degree & & \\
\hline S1 (Bachelor) & 61 & 84.72 \\
\hline S2 (Master) & 11 & 15.28 \\
\hline Teaching experience (Years) & & 40.3 \\
\hline $0-10$ & 29 & 41.7 \\
\hline $11-20$ & 30 & 18
\end{tabular}

Table 2. Student demography

\begin{tabular}{ccc}
\hline Demographich & Total & Percent \\
\hline Gender & & \\
\hline Male & 49 & 68.1 \\
\hline Female & 23 & 31.9 \\
\hline Age (in years) & & \\
\hline 13 & 13 & 18.1 \\
\hline 14 & 40 & 55.5 \\
\hline 15 & 19 & 26.4 \\
\hline
\end{tabular}

\subsection{Measurement}

In this study, the classical assumption and double regression test (analysis) was conducted. Furthermore, prerequisite tests were also conducted using normality, multicollinearity, heteroscedasticity, and autocorrelation tests. Furthermore, double regression test was done using both simultaneous and partial analysis. 


\subsection{Data Analysis}

\section{A. Descriptive statistics}

Table 3. Descriptive Statistic

\begin{tabular}{|c|c|c|c|c|c|c|c|c|}
\hline & \multirow{2}{*}{\begin{tabular}{|c|}
$\mathrm{N}$ \\
Statistic \\
\end{tabular}} & \multirow{2}{*}{$\begin{array}{l}\text { Range } \\
\text { Statistic }\end{array}$} & \multirow{2}{*}{$\begin{array}{c}\begin{array}{c}\text { Minimu } \\
\mathrm{m}\end{array} \\
\text { Statistic }\end{array}$} & \multirow{2}{*}{$\begin{array}{l}\text { Maximum } \\
\text { Statistic }\end{array}$} & \multicolumn{2}{|c|}{ Mean } & \multirow{2}{*}{$\begin{array}{c}\text { Std. } \\
\text { Deviation }\end{array}$} & \multirow{2}{*}{$\begin{array}{l}\text { Variance } \\
\text { Statistic }\end{array}$} \\
\hline & & & & & Statistic & $\begin{array}{l}\text { Std. } \\
\text { Error }\end{array}$ & & \\
\hline \multirow{6}{*}{$\begin{array}{l}\text { Student } \\
\text { Attitude } \\
\text { Teacher Values } \\
\text { Classroom } \\
\text { atmosphere } \\
\text { Student- } \\
\text { Teacher } \\
\text { Relationship } \\
\text { Valid N } \\
\text { (listwise) }\end{array}$} & 72 & 35 & 92 & 127 & 110.85 & .781 & 6.626 & 43.906 \\
\hline & 72 & 22 & 58 & 80 & 68.28 & .744 & 6.312 & 39.837 \\
\hline & 72 & 17 & 43 & 60 & 50.58 & .459 & 3.892 & 15.148 \\
\hline & 72 & & 31 & 53 & 3793 & 419 & 3554 & 12620 \\
\hline & & & & & & & & \\
\hline & 72 & & & & & & & \\
\hline
\end{tabular}

\section{B. Classical Assumption Test \\ I. Normality Test}

Table 4. Kolmogorov Smirnov Normality Test

\begin{tabular}{|l|l|}
\hline & Kolmogorov Smirnov Normality Test \\
\hline Asymp. Sig (2-tailed) & 0,850 \\
\hline
\end{tabular}

Based on table 4 , the significant value was 0.085 when compared to significance rate of $\alpha=0,05$, which showed $0.085>0.05$, therefore, $\mathrm{H}_{0}$ was accepted (not rejected). It could be concluded that the three independent variables were normally distributing.

\section{Multicollinearity test}

The measurement of multicollinearity test values showed that the tolerance measurement $>0,10$, and VIF measurement $>10$.

Table 5. Multicollinearity test

\begin{tabular}{|l|l|}
\hline \multicolumn{2}{|c|}{ Table of Multicollinearity test } \\
\hline Tolerance & VIF \\
\hline 0,916 & 1,092 \\
\hline 0,901 & 1,110 \\
\hline 0,982 & 1,019 \\
\hline
\end{tabular}

From table 5, the result could be seen below:

a. Tolerance Measurement

1.) Variable of Teacher values $0,916>0,100$, no multicollinearity occurred.

2.) Variable of Classroom atmosphere 0,901 > 0,100, no multicollinearity occurred.

3.) Variable of Student-teacher Relationship 0,982 > 0,100, no multicollinearity occurred.

b. VIF Measurement

1.) Variable of Teacher values $1,092<10$, no multicollinearity occurred. 
2.) Variable of Classroom atmosphere 1,110 < 10, no multicollinearity occurred.

3.) Variable of Student-teacher Relationship 1,019 < 10, no multicollinearity occurred.

Based on the analysis, it could be concluded that there was no multicollinearity in the three variables (teacher values, classroom atmosphere, and studentteacher relationship).

\section{Heteroscedasticity test}

Heteroscedasticity test is used to determine the availability of different variables in the regression model. The data were transformed into an absolute residual form, which was analyzed using Glejser test. The result of the test are written below.

Table 6. Result of Heteroscedasticity test

\begin{tabular}{|l|l|l|}
\hline \multicolumn{3}{|c|}{ Table of Heteroscedasticity test } \\
\hline & Sig. & Result \\
\hline Teacher Values & $0,310>0,05$ & No Heteroscedasticity \\
\hline Classroom atmosphere & $0,193>0,05$ & No Heteroscedasticity \\
\hline Student teacher-relationship & $0,760>0,05$ & No Heteroscedasticity \\
\hline
\end{tabular}

Based on table 6, no heteroscedasticity was identified among the three variables.

\section{The similarity of Regression Line}

The result of the regression line similarity could be seen in table 7 .

Table 7. Regression line similarity

\begin{tabular}{|l|l|}
\hline Variable & Coefficient of Regression \\
\hline Constant & 67,306 \\
\hline Teacher Values & $-0,065$ \\
\hline Classroom atmosphere & 0,807 \\
\hline Student teacher relationship & 0,188 \\
\hline
\end{tabular}

The measurement of double linear regression using SPPS program could be seen below.

The equation of linier regression was written below:

$$
\mathrm{Y}=67,306-0,065+0,807+0,188
$$

The coefficients written above can be broken down into the following sections:

1) Constant (a) with 67, 306 means the independent variable (consist of classroom atmosphere) is considered constant. Therefore student attitude counts 67,306 .

2) The regression coefficient of teacher values with - 0, 065 means for every additional individual the increasing point of teacher values decreases student attitude by $-0,065$, while for every additional student, the decreasing point of teacher value will increase student attitude by $-0,065$.

3) The regression coefficient of classroom atmosphere with 0,087 means for every additional increasing ratio of classroom atmosphere there will be an increase in 
the student by 0,807 , while every additional decreasing ratio of classroom atmosphere will decrease student attitude about 0,807 .

4) The regression coefficient of student-teacher relationship with 0,188 means every additional increasing ratio of the student-teacher relationship increases student attitude about 0,188 while every additional decreasing ratio of student-teacher relationship decreases student attitude about 0,188 .

\section{Hypothesis Analysis}

\section{Hypothesis 1}

To prove hypothesis 1 , the partial test was conducted with the result written below in table 8 .

Table 8. The result from Partial Analysis of Hypothesis 1

\begin{tabular}{|c|c|c|c|c|}
\hline \multicolumn{5}{|c|}{ Variable of teacher values } \\
\hline Variable & & Sig. & R square & Result \\
\hline $\begin{array}{ll}\text { Teacher value } \\
\text { attitude }\end{array}$ & toward & 0,851 & 0,006 & Not significant \\
\hline
\end{tabular}

Table 8 showed the calculation of significance that reached 0,851 , and $\mathrm{R}$ square that reached 0, 006. Assuming it was compared to a significant rate of 0,05 its showed $0,851>0,05$. Therefore, it could be concluded that partial test of teacher values towards student attitude is not significant, but it still gave an impact on 0 , 06 , or $6 \%$.

\section{Hypothesis 2}

To prove hypothesis 2, the partial test was conducted with the result written below in table 9 .

Table 9. Result from Partial Analysis of Hypothesis 2

\begin{tabular}{|l|l|l|l|}
\hline \multicolumn{4}{|c|}{ Variable of Classroom Atmosphere } \\
\hline Variable towards & 0,000 & 0,221 & Significant \\
\hline $\begin{array}{l}\text { Classroom atmosphere } \\
\text { Students Attitude }\end{array}$ & & R square & Result \\
\hline
\end{tabular}

Table 9 showed the calculation of significance that reached 0,000 , and $\mathrm{R}$ square that reached 0,221. Assuming it was compared to significant rate 0,05 it showed $0,000<0,05$. It could be concluded that partial test of classroom atmosphere towards student attitude is significant and gave the impact of 0,221 or $2,21 \%$.

\section{Hypothesis 3}

To prove hypothesis 3 , the partial test was conducted with the result written below in table 10 .

Table 10. Result from Partial Analysis of Hypothesis 3

\begin{tabular}{|l|c|c|c|}
\hline \multicolumn{4}{|c|}{ Variable of Student-teacher Relationship } \\
\hline Variable & Sig. & R square & Result \\
\hline $\begin{array}{l}\text { Student-teacher Relationship towards } \\
\text { Students Attitude }\end{array}$ & 0,350 & 0,026 & Not significant \\
\hline
\end{tabular}


Table 10 showed the calculation of significance that reached 0,350 , and $\mathrm{R}$ square of 0,26 . When compared to a significant rate of 0,05 it showed $0,350>0,05$. It could be concluded that partial test of student-teacher relationship towards student attitude is not significant, but it still gave the impact of 0,026 or 2, $6 \%$.

\section{Hypothesis 4}

To prove hypothesis 4 , the percentage of two variables were tested at the same time using path analysis. The result is written below in table 11.

Table 11. The result from Path Analysis of Hypothesis 4

\begin{tabular}{|l|c|c|}
\hline \multicolumn{3}{|c|}{ Variable of Teacher values E Class Atmosphere } \\
\hline Variable & Structural Coefficient & R square \\
\hline Teacher values and classroom & Teacher values $=-0,61$ & 0,224 \\
atmosphere towards Students & Classroom atmosphere $=0,448$ & \\
\cline { 2 - 2 } Attitude & & \\
\hline
\end{tabular}

The structural equation of table 11 was written below.

$$
\mathrm{Y}=-0,61 \mathrm{X} 1+0,488 \times 2
$$

Y: Student attitude X1: Teacher values X2: Classroom atmosphere

Teacher values have a negative coefficient of $-0,6$. It means that for every additional decrease of teacher the value, there would probably be a decrease in student attitude by $-0,61$, while assuming that there was no change in the classroom atmosphere with a positive coefficient of 0,488 . It means that for every additional increasing of classroom atmosphere, there would probably be an increase in student attitude by $-0,488$, with the assumption there was no change in teacher values. The table above showed $\mathrm{R}$ square reached 0,224 from two variable combinations. It could be concluded that path analysis of teacher values and classroom atmosphere towards student attitude gave an impact of 0, 224 or $22,4 \%$.

\section{Hypothesis 5}

To prove hypothesis 5, the percentage of two variables needed to be tested at the same time using path analysis. The result was shown below in table 12.

Table 12. Result from Path Analysis of Hypothesis 5

\begin{tabular}{|l|l|l|}
\hline Variable of Classroom Atmosphere \& Student-teacher Relationship \\
\hline Variable & Structural Coefficient & R square \\
\hline Classroom atmosphere and & Classroom Atmosphere = & 0,231 \\
Student-teacher Relationship & 0,456 & \\
\cline { 2 - 3 } towards Students Attitude & $\begin{array}{l}\text { Student-teacher } \\
\text { Relationship }=0,100\end{array}$ & \\
\hline
\end{tabular}

The structural equation of the table 12 was written below.

$$
\mathrm{Y}=0,456 \mathrm{X} 2+0,100 \times 3
$$

$\mathrm{Y}=$ Student Attitude X2 = Classroom Atmosphere, $\mathrm{X} 3$ = Student-teacher Relationship 
Classroom atmosphere has a positive coefficient of 0,456 . Therefore, for every additional increase of classroom atmosphere there would probably be an increase in student attitude by $-0,61$, with the assumption there was no change in the student-teacher relationship because it has a positive coefficient of 0,100 . For every additional increasing of student-teacher relationship, there would probably be an increase in student attitude by 0,100 , with the assumption there was no change in the classroom atmosphere. The table above showed $\mathrm{R}$ square reached 0, 231 from two variable combinations. It could be concluded that path analysis of classroom atmosphere and student-teacher relationship towards student attitude gave the impact of 0,231 or $23,1 \%$.

\section{Hypothesis 6}

To prove hypothesis 6 , the percentage of two variables was tested at the same time using path analysis. The result was written below in table 13.

Table 13. The result from Path Analysis of Hypothesis 6

\begin{tabular}{|l|l|l|}
\hline \multicolumn{3}{|l|}{ Variable of Teacher Values \& Student-teacher Relationship } \\
\hline Variable & Structural Coefficient & R square \\
\hline Teacher Values and Student- & Teacher Values =0,073 & 0,032 \\
\cline { 2 - 2 } $\begin{array}{l}\text { teacher Relationship towards } \\
\text { Students Attitude }\end{array}$ & $\begin{array}{l}\text { Student-teacher } \\
\text { Relationship }=0,159\end{array}$ & \\
\hline
\end{tabular}

The structural equation of the table 12 was written below.

$$
\mathrm{Y}=0,073 \mathrm{X} 1+0,159 \mathrm{X} 3
$$

$\mathrm{Y}=$ Student Attitude X1 = Classroom Atmosphere, $\mathrm{X} 2$ = Student-teacher Relationship

Teacher values have a positive coefficient of 0,073 . For every additional increasing of teacher values there would be an increase in student attitude by 0 , 073, with the assumption that there was no change in the student-teacher relationship as it contained a positive coefficient of 0,159 . Every additional increase in a student-teacher relationship would probably increase student attitude by 0,159 , with the assumption that there was no change in teacher values. The table above showed $\mathrm{R}$ square reached 0,032 from two variable combinations. It could be concluded that path analysis of teacher values and student-teacher relationship towards student attitude gave an impact of 0,032 or $3,2 \%$.

\section{Hypothesis 7}

The significant test that was simultaneously conducted using the F Test could be seen in the table ANOVA. It aimed to know the existence of teacher values, classroom atmosphere, and student-teacher relationship towards student attitude.

Table 14. Simultaneous Test

\begin{tabular}{|l|l|l|l|}
\hline \multicolumn{4}{|l|}{ Table of Simultaneous Test } \\
\hline Variable & Sig. & R square & Result \\
\hline X1, X2, and X3 & 0,000 & 0,234 & Significant \\
\hline
\end{tabular}


The result of the simultaneous test using significance rate, showed 0,000 , which means $0,000<0,05$; therefore, Ho was rejected. It could be concluded that teacher values, classroom atmosphere, and student-teacher relationship were simultaneously impacted on student attitude by 0,234 or $23,4 \%$.

\section{Discussion and Conclusion}

This study aimed to prove the impact of teacher values, classroom atmosphere, and student-teacher relationship towards student attitude during the learning process, both partially and simultaneously. The data analysis is shown in figure 3 below.

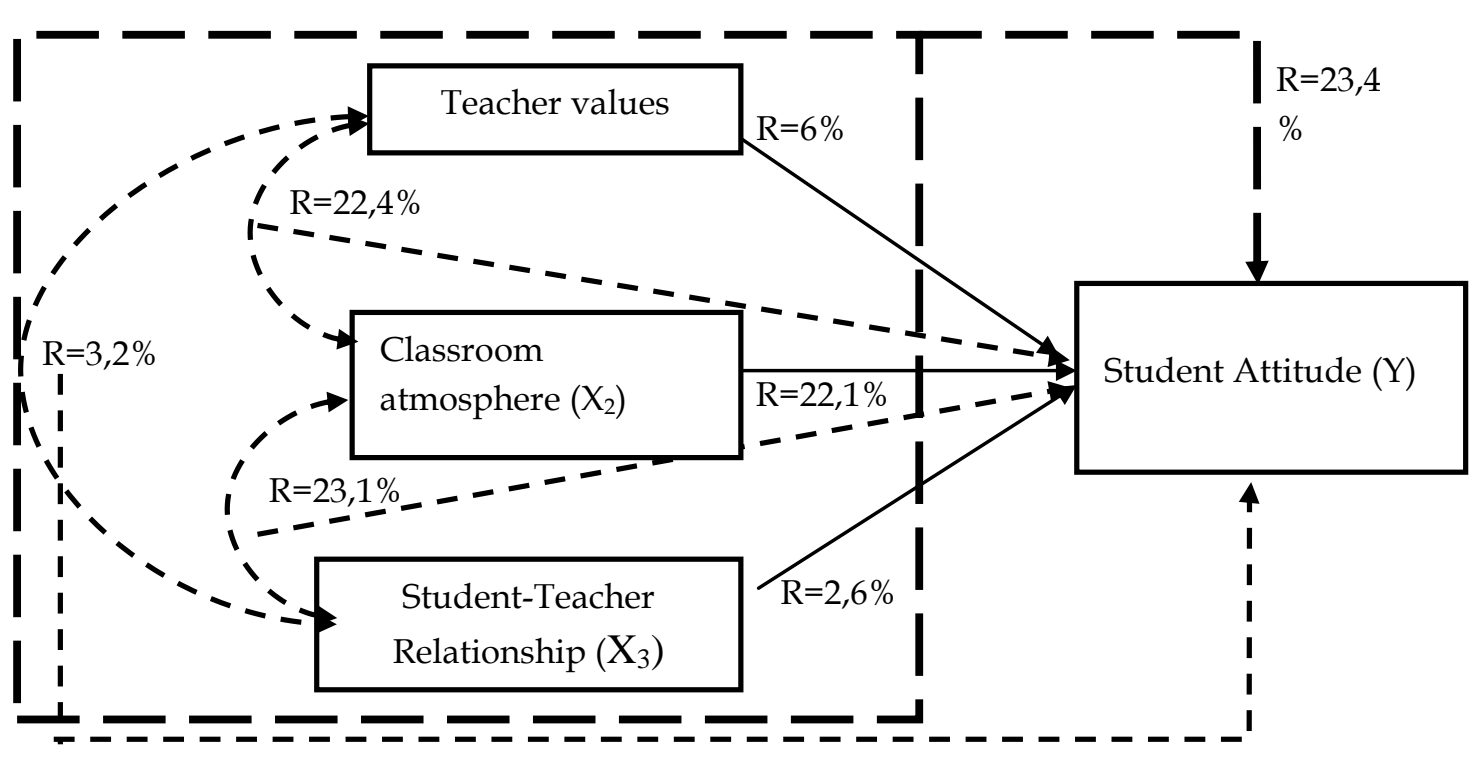

Figure 3. Result of Influence Test between Independent and Dependent Variables

Based on figure 3, in the first hypothesis $X_{I}$ with relation coefficient $R=6 \%$ towards $Y$ showed that the teacher values partially gave impact towards student attitude by $6 \%$. In the second hypothesis, $X_{2}$ with relation coefficient $R=22,1 \%$ towards $\mathrm{Y}$, indicated a positive impact of classroom atmosphere towards student attitude by 22, 1\%, without a significance. Hypothesis 3 with coefficient $R=2$, had a $6 \%$ impact towards Y. It indicated that there was a positive impact of student-teacher relationship towards student attitude. In the fourth hypothesis, $\mathrm{X}_{1}-\mathrm{X}_{2}$ with coefficient towards $\mathrm{Y}$ reached $\mathrm{R}=22,4 \%$. It showed that teacher values and classroom atmosphere were simultaneously giving impact on student attitude about 22, 4\%. Hypothesis $5, \mathrm{X}_{2}-\mathrm{X}_{3}$ with relation coefficient $\mathrm{R}=$ $22,1 \%$ towards $\mathrm{Y}$ showed that there was a simultaneous positive impact of classroom atmosphere and student-teacher relationship towards student attitude that reached about $22,1 \%$. The sixth hypothesis, $X_{1}-X_{3}$ with relation coefficient $R$ $=3$, which is $2 \%$ towards showed a simultaneous positive impact of teacher values and student-teacher relationship towards student attitude by 3, 2\%. Hypothesis $7, X_{1}, X_{2}$, and $X_{3}$ with coefficient $R=23,4 \%$ towards $Y$ showed that 
there was a simultaneous impact of teacher values, classroom atmosphere, and student-teacher relationship towards student attitude that reached 23, $4 \%$.

Based on the hypothesis test conducted, four findings of the study was found. In the first, classroom atmosphere was the only variable that had a significant impact on student attitude when it was examined using partial test. This finding was in line with the previous study which showed the positive impact of classroom atmosphere towards student attitude as stated by NICHD ECCRN (2005), Wilson et al., (2007), and Limpo et al. (2013).

The impact of classroom atmosphere towards student attitude was caused by the high intensity of student-teacher relationship which leads to a positive and supportive impact on students thereby, enabling them develop their capability of self-control and conflict management (Hamre \& Pianta, 2005; Wilson et al., 2007; Thomas et al., 2011; Xu et al., 2018; Yang \& MacLeod, 2019; Lee et al., 2019). The classroom atmosphere is also significantly related to student participation, involvement in the learning process, and assignment completion (Andersosn et al., 2004). It is also the manifestation of both student-teacher and studentstudent interaction during the learning process. Good classroom atmosphere develops student attitude towards the learning process since it portrays a good teacher-student relationship. Classroom atmosphere has three components that probably could increase student attitude during learning process this include1) classroom organization based on well standard behavior and awareness towards other people, b) several roles by teachers in supporting students, and c) teacher enthusiasm towards students.

There are at least three dimensions of classroom atmosphere in which give impact to student attitude. The first is the relationship dimension that shows a positive relationship between student-teacher and student-student, which is full of warmth, trust, support. It eliminates social border, which usually leads to prejudice, inconvenience, and conflict. Relationship dimension also gives impact on student behavior in the classroom. Secondly, self-development dimension portrays the development of student ability as the impact of the process occurred in the classroom. Thirdly, maintenance, and system change dimension portray regularity and harmony of environment therefore, it supports students in the process to adapt to every condition faced at school.

There was no significant impact on teacher values on student attitude during the learning process. However, this finding was different from previous studies, which showed the impact of teacher values on student attitude. A study from O'Sullivan (2005) and Lovat (2007a) also proved that teacher values impacted towards student attitude. They stated that teacher consideration of values would impact to the way they teach and treat their students. Teachers were demanded to always express their values therefore the learning process would go smoothly (Willemse et al., 2005).

This study was also different from Suyatno et al. (2019a), which showed that teacher values provides an impact to the way teachers taught and treated their students. These values shaped their learning style. Teachers with pedagogical learning style (student-teacher close relationship, entertaining and interactive 
learning style) make students be more enthusiastic, and interested in the learning process. Teachers that possess particular values tend to be able to create pedagogical learning techniques. Their impact on student attitude is also caused by professionalism. Teachers with good professionalism will attract students to have a positive attitude during the learning process (Suyatno et al., 2019b). The finding of this study was also different from Chong and Cheah (2009) study, which stated that teachers with particular values tend to cherish their job since it is something that comes from their internal factor. Their passion for their job pushes them to develop their professionalism.

Thirdly, there was no impact between student-teacher relation and student attitude. This finding was different from the previous study conducted by some researchers (Espelage \& Swearer, 2003; Rodkin \& Hodges, 2003; Gini et al. 2015; Stuhlman \& Pianta, 2002; Hughes \& Im, 2016). Other studies also showed the same tendency that student-teacher relationship gave impact on student attitude, either directly or indirectly. Gest et al. (2005) found that their support could attract student interest, thereby leading to their positive attitude. The quality of the relationship between student and teacher could increase student attitude in the classroom (Eisenberg et al., 2005). The supportive relationship between students and teacher creates a positive attitude. Therefore, students tend to develop their problem-solving skill, self-regulation, and effective interaction with other people (Pianta, 2006).

The impact of student-teacher relationship towards student attitude was caused by the capability of teachers in building a great bond. They tend to have great pedagogical skill, especially in communication, which is a pre-requisite aspect of creating a good quality relationship with students. It could lead to the effective learning process (Suyatno et al., 2019b). During this period, the main responsibility of teachers is to deliver verbal and nonverbal messages to their students. Effective communication would give impact on student achievement. Therefore a well-delivered message will create a positive impact on students (Arends, 2013).

Fourthly, all independent variables showed the impact towards student attitude assuming it was tested simultaneously with positive simultaneous impact of 1) teacher values on student attitude; 2) teacher values and classroom atmosphere with student attitude; 3) student-teacher relationship and classroom atmosphere with their attitude; 4) teacher values, student-teacher relationship, and classroom atmosphere with student attitude. The result of the simultaneous test showed that these three independent variables are used as the instruments to develop student attitude.

The differences between this research and the previous studies were caused by some possibilities, namely 1) The sample size which comprises of (Azwar, 2000) seventy-two students and teachers $(\mathrm{N}=72)$ as more respondents are needed in subsequent studies. 2) The technique of data collection is probably becoming another reason (teacher values and the student-teacher relationship was collected based on teacher perception) while other variables (classroom atmosphere and student attitude) were collected based on student perception. Based on data analysis, variable $X$ provided a significant impact towards $Y$ was 
only classroom atmosphere as data was taken from the same variable $Y$ (students). However, two independent variables (teacher values and studentteacher relationship) were collected from teachers and how they portrayed themselves would be somewhat different from students.

\section{Recommendation}

Based on the finding of this study, factors, and training capable of elevating classroom atmosphere have to be found since it is the variable that develops student attitude. In addition, more significant amount of respondents and technic in collecting the data need to be taken into consideration to reveal the reason and factors why this research is different from previous studies.

\section{Acknowledgement}

The researchers thank the Directorate General of Research and Development Strengthening (Ministry of Research, Technology and Higher Education of Republic of Indonesia) for giving grant of research schema, Basic Research of Superior University (PDUPT), and Universitas Ahmad Dahlan, Indonesia.

\section{References}

Adegboyega, L. O. (2018). Influence of Achievement Motivation on Nigerian Undergraduates' Attitude towards Examination. International Journal of Instruction, 11(1), 77-88. https://doi.org/10.12973/iji.2018.1116a

Adesoji, F. A. (2008). Managing students' attitude towards science through problemsolving instructional strategy. The Anthropologist, 10(1), 21-24. https://doi.org/10.1080/09720073.2008.11891024

Anderson, A., Hamilton, R. J., \& Hattie, J. (2004). Classroom climate and motivated behaviour in secondary schools. Learning environments research,7(3), 211-225. https://doi.org/10.1007/s10984-004-3292-9

Arends, R. I. (2013). Learning to Teach 2. Jakarta: Salemba Humanika.

Azwar, S. (2000). Sikap Manusia: Teori dan Pengukurannya [Human Attitude: Theory and Measurement. Yogyakarta: Pustaka Pelajar.

Baek, S.G \& Choi, H.J. (2002). The relationship between students' perceptions of classroom environment and their academic achievement in Korea. Asia Pacific Education Review, 3(1), 125-135. https://doi.org/10.1007/bf03024926

Bakar, K. A., Tarmizi, R. A., Mahyuddin, R., Elias, H., Luan, W. S., \& Ayub, A. F. M. (2010). Relationships between university students' achievement motivation, attitude and academic performance in Malaysia. Procedia-Social and Behavioral Sciences, 2(2), 4906-4910. https://doi.org/10.1016/j.sbspro.2010.03.793

Blair, C. (2002). School readiness: Integrating cognition and emotion in a neurobiological conceptualization of children's functioning at school entry. American Psychologist, 57, 111-127. https://doi.org/10.1037//0003-066x.57.2.111

Bohner, G., \& Wänke, M. (2002). Attitudes and attitude change. Psychology Press.

Bossér, U., \& Lindahl, M. (2019). Students' positioning in the classroom: A study of teacher-student interactions in a socioscientific issue context. Research in science education, 49(2), 371-390. https://doi.org/10.1007/s11165-017-9627-1 
Bramlett, D. C. \& Herron, S. (2009). A study of African-American College students' attitude towards mathematics. Journal of Mathematical Sciences \& Mathematics Education, 4(2), 43-51.

Chong, S. N. Y., \& Cheah, H. M. (2009). A values, skills and knowledge framework for initial teacher preparation programmes. Australian Journal of Teacher Education, 34(3), 1-17. https://doi.org/10.14221/ajte.2009v34n3.1

Decker, D. M., Dona, D. P., \& Christenson, S. L. (2007). Behaviorally at-risk African American students: The importance of student-teacher relationships for student outcomes. Journal of School Psychology, 45, 83-109. https://doi.org/10.1016/j.jsp.2006.09.004

Djaali. (2009). Psikologi Pendidikan [Educational Psychology] Jakarta: PT. Bumi Aksara.

Eisenberg, N., Zhou, Q., Spinrad, T. L., Valiente, C., Fabes, R. A., \& Liew, J. (2005). Relations among positive parenting, children's effortful control, and externalizing problems: A three-wave longitudinal study. Child Development, 76, 1055-1071. https://doi.org/10.1111/j.1467-8624.2005.00897.x

Espelage, D. L., \& Swearer, S. M. (2003). Research on school bullying and victimization: What have we learned and where do we go from here? School Psychology Review, 32(3), 365-384.

Ezeife, A. N. \& Smith, C. B. (2010). The relationship between students' perceptions of their classroom environment and their attitudes toward science in grade nine applied science classes. Academic Exchange EXTRA.

Fraire, M., Longobardi, C., Prino, L. E., Sclavo, E., \& Settanni, M. (2013). Examining the student-teacher relationship scale in the Italian context: A factorial validity study. Electronic Journal of Research in Educational Psychology, 11(3), 851-882. http://dx.doi.org/10.14204/ejrep.31.13068.

Furrer, C., \& Skinner, E. (2003). Sense of relatedness as a factor in children's academic engagement and performance. Journal of Educational Psychology, 95, 148-162. https://doi.org/10.1037//0022-0663.95.1.148

Gest, S. D., Welsh, J. A., \& Domitrovich, C. E. (2005). Behavioral predictors of changes in social relatedness and liking school in elementary school. Journal of School Psychology, 43, 281-301. https:// doi.org/10.1016/j.jsp.2005.06.002

Gini, G., Pozzoli, T., \& Bussey, K. (2015). The role of individual and collective moral disengagement in peer aggression and bystanding: A multilevel analysis. Journal of abnormal child psychology, 43(3), 441-452. http://dx.doi.org/10.1007/s10802-0149920-7.

Hamre, B. K., \& Pianta, R. C. (2001). Early teacher-child relationships and the trajectory of children's school outcomes through eighth grade. Child Development, 72, 625638. http://dx.doi.org/10.1111/1467-8624.00301.

Hamre, B. K., \& Pianta, R. C. (2005). Can instructional and emotional support in the firstgrade classroom make a difference for children at risk of school failure? Child Development, 76, 949-967. https://doi.org/10.1111/j.1467-8624.2005.00889.x

Hamre, B. K., Pianta, R. C., \& Downer, J. (2006, May). Social resources in the classroom and young children's academic and social development. Paper presented at the meeting of the Society for Prevention Research, San Antonio, TX.

Howes, C. (2000). Social- emotional classroom climate in child care, child- teacher relationships and children's second grade peer relations. Social development, 9(2), 191-204. https:/ / doi.org/10.1111/1467-9507.00119

Hughes, J. N., \& Im, M. H. (2016). Teacher-student relationship and peer disliking and liking across grades 1-4. Child Development. http://dx.doi.org/10.1111/cdev. 12477.

Hughes, J. N., Luo, W., Kwok, O. M., \& Loyd, L. K. (2008). Teacher-student support, effortful engagement, and achievement: A 3-year longitudinal study. Journal of Educational Psychology, 100, 1-14. https://doi.org/10.1111/cdev.12477 
Ifamuyiwa, S.A. \& M.K. Akinsola, (2008). Improving senior secondary school students attitude towards mathematics through self and cooperative instructional strategies. Int. J. Math. Educ. Sci., Technol., 39: 569-585. https://doi.org/10.1080/00207390801986874

Jungert, T., Piroddi, B., \& Thornberg, R. (2016). Early adolescents' motivations to defend victims in school bullying and their perceptions of student-teacher relationships: A self-determination theory approach. Journal of Adolescence, 53, 75-90. https://doi.org/10.1016/j.adolescence.2016.09.001

Karpouza, E., \& Emvalotis, A. (2019). Exploring the teacher-student relationship in graduate education: a constructivist grounded theory. Teaching in higher education, 24(2), 121-140. https://doi.org/10.1080/13562517.2018.1468319

Klein, M. (2004). The premise and promise of inquiry based mathematics in pre-service teacher education: A poststructuralist analysis. Asia-Pacific Journal of Teacher Education, 32(1), 35-47. https://doi.org/10.1080/1359866042000206008

Klem, A. M., \& Connell, J. P. (2004). Relationships matter: Linking teacher support to student engagement and achievement. Journal of School Health, 74, 262-273. http://dx.doi.org/10.1111/j.1746-1561.2004.tb08283.x.

Köğce, D., Yıldız, C., Aydın, M. \& Altındağ, R., (2009). Examining Elementary School Students Attitudes towards Mathematics in Terms of Some Variables, Procedia Social and Behavioral Sciences, 1(1), 291-295. https://doi.org/10.1016/j.sbspro.2009.01.053

Kutsyuruba, B., Klinger, D. A., \& Hussain, A. (2015). Relationships among school climate, school safety, and student achievement and well- being: a review of the literature. Review of Education, 3(2), 103-135. https:// doi.org/10.1002/rev3.3043

Ladd, G. W., \& Burgess, K. B. (2001). Do relational risks and protective factors moderate the linkages between childhood aggression and early psychological and school adjustment? Child Development, 72, 1579-1601. https://doi.org/10.1111/14678624.00366

Ladd, G. W., \& Dinella, L. M. (2009). Continuity and change in early school engagement: Predictive of children's achievement trajectories from first to eighth grade? Journal of Educational Psychology, 101(1), 190. https://doi.org/10.1037/a0013153

Ladd, G. W., Herald-Brown, S. L., \& Reiser, M. (2008). Does chronic classroom peer rejection predict the development of children's classroom participation during the grade school years? Child Development, 79, 1001- 1015. https://doi.org/10.1111/j.1467-8624.2008.01172.x

Lee, Y., Yang, H. H., MacLeod, J., \& Dai, J. (2019). Developing the rotational synchronous teaching (RST) model: Examination of the connected classroom climate. Australasian Journal of Educational Technology, 35(1). https://doi.org/10.14742/ajet.4010

Lickona, T. (2004). Character Matter. New York: Touchstone Rockefeller Center.

Limpo, J. N., Oetomo, H., \& Suprapto, M. H. (2013). Pengaruh lingkungan kelas terhadap sikap siswa untuk pelajaran matematika [The influence of the classroom environment on students' attitudes to mathematics]. Humanitas: Jurnal Psikologi Indonesia, 10(1), 37-48.

Liu, Y., Li, X., Chen, L., \& Qu, Z. (2015). Perceived positive teacher-student relationship as a protective factor for Chinese left- behind children's emotional and behavioural adjustment. International Journal of Psychology,50(5), 354-362. https://doi.org/10.1002/ijop.12112

Lockwood, A.L. (2009). The case for character education: A developmental approach. New York, NY: Teachers College Press.

Longobardi, C., Prino, L. E., Marengo, D., \& Settanni, M. (2016). Student-teacher relationships as a protective factor for school adjustment during the transition 
from middle to high school. Frontiers in psychology, 7 . https://doi.org/10.3389/fpsyg.2016.01988

Lovat, T. (2007a). Synergies and Balance between Values Education and Quality Teaching. Paper presented at the Moral Education and Australian Values Conference. Retrieved 28 November, 2010. https://doi.org/10.1111/j.1469-5812.2008.00469.x

Lucas-Molina, B., Williamson, A. A., Pulido, R., \& Pérez-Albéniz, A. (2015). Eff ects of teacher-student relationships on peer harassment: A multilevel study. Psychology in the Schools, 52, 298-315. http://dx.doi.org/10.1002/pits.21822.

Mercer, S. H., \& DeRosier, M. E. (2008). Teacher preference, peer rejection, and student aggression: A prospective study of transactional influence and independent contributions to emotional adjustment and grades. Journal of School Psychology, 46, 661-685. https://doi.org/10.1016/j.jsp.2008.06.006

Mohamed, L., \& Waheed, H. (2011). Secondary students' attitude towards mathematics in a selected school of Maldives. International Journal of humanities and social science, 1(15), 277-281.

Mohd, N., Mahmood, T. F. P. T., \& Ismail, M. N. (2011). Factors that influence students in mathematics achievement. International Journal of Academic Research, 3(3), 49-54.

NICHD Early Child Care Research Network. (2005). A day in third grade: A large-scale study of classroom quality and student behavior. Elementary School Journal, 105, 305-323. https://doi.org/10.1086/428746

Nicolaidou, M. \& Philippou, G. (2003). Attitudes towards mathematics, self-efficacy and achievement in problem solving. European Research in Mathematics III.

O'sullivan, S. (2005). The soul of teaching: Educating teachers of character. Action in Teacher education, 26(4), 3-9. https:/ / doi.org/10.1080/01626620.2005.10463338

Papanastasiou, C. (2000). Effects of attitudes and beliefs on mathematics achievement. Studies in Educational Evaluation, 26, 27-42. https://doi.org/10.1016/s0191491x(00)00004-3

Patrício, J. N., Barata, M. C., Calheiros, M. M., \& Graça, J. (2015). A Portuguese version of the student-teacher relationship scale-short form. The Spanish journal of psychology, 18. https://doi.org/10.1017/sjp.2015.29

Pianta, R. C. (2006). Teacher-child relationships and early literacy. In D. Dickinson \& S. Neuman (Eds.), Handbook of early literacy research (Vol. 2, pp. 149-162). New York: Guilford Press.

Pianta, R. C., \& Stuhlman, M. W. (2004). Teacher-child relationships and children's success in the first years of school. School Psychology Review, 33, 444-458.

Pianta, R. C., Belsky, J., Vandergrift, N., Houts, R., \& Morrison, F. J. (2008). Classroom effects on children's achievement trajectories in elementary school. American Educational Research Journal, 45, 365-397. https:// doi.org/10.3102/0002831207308230

Print, M. (2000). Curriculum Policy, Values and Changes in Civics Education in Australia Asia Pacific Journal of Education, 20(1), 21-35. https://doi.org/10.1080/0218879000200103

Quaglia, R., Gastaldi, F. G. M., Prino, L. E., Pasta, T., \& Longobardi, C. (2013). The pupilteacher relationship and gender diff erences in primary school. Open Psychology Journal, 6, 69-75. https://doi.org/10.2174/1874350101306010069

Ramirez, M. J. (2005). Attitudes toward mathematics and academic performance among Chilean 8th graders. Estudios Pedagogicos, 1, 97-112. https://doi.org/10.4067/s0718-07052005000100006

Rivera, T. C., \& Ganaden, M. F. (2001). Classroom psychosocial environment. International Online Journal of Science and Mathematics Education, 1.

Rodkin, P. C., \& Hodges, E. V. E. (2003). Bullies and victims in the peer ecology: Four questions for psychologists and school professionals. School Psychology Review, 32(3), 384-400. 
Sahin, C. (2015). Determination of tendencies of secondary school students to tolerance and variables affecting their tendencies to tolerance. The Anthropologist, 20(3), 599615. https://doi.org/10.1080/09720073.2015.11891764

Scrimin, S., Moscardino, U., Altoè, G., \& Mason, L. (2018). Attentional bias for academic stressors and classroom climate predict adolescents' grades and socioemotional functioning. Journal of Research on Adolescence, 28(1), 245-258. https://doi.org/10.1111/jora.12329

Senturk, L., \& Aktas, E. (2015). Comparison of Turkish language textbooks for natives in Turkey and in Romania according to value education. Journal of Values Education, 13, 215-243.

Settanni, M., Longobardi, C., Sclavo, E., Fraire, M., \& Prino, L. E. (2015). Development and psychometric analysis of the student-teacher relationship scale-short form. Frontiers in psychology, 6, 898. https://doi.org/10.3389/fpsyg.2015.00898

Slameto (2010). Belajar dan Faktor-Faktor yang Mempengaruhinya [Learning and Factors That Influence It]. Jakarta: Rineke Cipta.

Spilt, J. L., Hughes, J. N., Wu, J. Y., \& Kwok, O. M. (2012). Dynamics of teacher-student relationships: Stability and change across elementary school and the influence on children's academic success. Child development, 83(4), 1180-1195. https://doi.org/10.1111/j.1467-8624.2012.01761.x

Stuhlman, M. W., \& Pianta, R. C. (2002). Teachers' narratives about their relationship with children: Associations with behavior in classrooms. School Psychology Review, 31(2), 148-163.

Suyatno, Pambudi, D.I., Mardati, A., Wantini, Nuraini, E., \& Yoyo (2019a). The Education Values of Indonesian Teachers: Origin, Importance, and Its Impact on Their Teaching. International Journal of Instruction, 12(3), 633-650. https://doi.org/10.29333/iji.2019.12338a

Suyatno, S., Wantini, W., Baidi, B., \& Amurdawati, G. (2019b). The Influence of Values and Achievement Motivation on Teacher Professionalism at Muhammadiyah 2 High School Yogyakarta, Indonesia. Pedagogika, 133(1). https://doi.org/10.15823/p.2019.133.6

Syah, M. (2010). Psikologi Pendidikan Dengan Pendekatan Baru [Educational Psychology with a New Approach]. Bandung: Remaja Rosdakarya.

Tahar, N. F., Ismail, Z., Zamani, N. D., \& Adnan, N. (2010). Students" Attitude Toward Mathematics: The Use of Factor Analysis in Determining the Criteria. ProcediaSocial and Behavioral Sciences, 8, 476-481. https://doi.org/10.1016/j.sbspro.2010.12.065

Thomas, D. E., Bierman, K. L., Powers, C. J., \& Conduct Problems Prevention Research Group. (2011). The influence of classroom aggression and classroom climate on aggressive-disruptive behavior. Child development, 82(3), 751-757. https://doi.org/10.1111/j.1467-8624.2011.01586.x

Thornberg, R., Thornberg, U. B., Alamaa, R., \& Daud, N. (2016). Children's conceptions of bullying and repeated conventional transgressions: moral, conventional, structuring and personal-choice reasoning. Educational Psychology, 36(1), 95-111. https://doi.org/10.1080/01443410.2014.915929

Tirri, K. (2010). Teacher values underlying professional ethics, in T. Lovat, R. Toomey and N. Clement (Eds). International research handbook on values education and student wellbeing. Dordrecht: Springer. https://doi.org/10.1007/978-90-481-8675-4_9

Tohirin. (2005). Psikologi Pembelajaran Pendidikan Agama Islam [Psychology of Islamic Religious Education Learning]. Jakarta: PT. Raja Grafindo Persada.

Velegol, S. B., \& Zappe, S. E. (2016). How does a flipped classroom impact classroom climate?. In 123rd ASEE Annual Conference and Exposition. American Society for Engineering Education. https://doi.org/10.18260/p.25479

Walgito, B. (2003). Psikologi social [Social psychology]. Yogyakarta: Andi Offset. 
Walker, S., \& Graham, L. (2019). At risk students and teacher-student relationships: student characteristics, attitudes to school and classroom climate. International Journal of Inclusive Education, 1-18. https://doi.org/10.1080/13603116.2019.1588925

Willemse, M., Lunenberg, M., \& Korthagen, F. (2005). Values in education: A challenge for teacher educators. Teaching and Teacher Education,21(2), 205-217. https://doi.org/10.1016/j.tate.2004.12.009

Wilson, H. K., Pianta, R. C., \& Stuhlman, M. (2007). Typical classroom experiences in first grade: The role of classroom climate and functional risk in the development of social competencies. Elementary School Journal, 108, 81-96. Howes, C. (2000). https://doi.org/10.1086/525548

Xu, J., Yang, H. H., \& MacLeod, J. (2018). STEP on connected classroom climate in a hybrid learning environment. International Journal of Innovation and Learning, 23(4), 430-443. https://doi.org/10.1504/ijil.2018.10011969

Yang, H. H., Feng, L., \& MacLeod, J. (2019). Understanding college students' acceptance of cloud classrooms in flipped instruction: integrating UTAUT and connected classroom climate. Journal of Educational Computing Research, 56(8), 1258-1276. https://doi.org/10.1177/0735633117746084

Yilmaz, C., Altun, S. A. \& Ollkun, S. (2010). Factors affecting students" attitude towards math: $\mathrm{ABC}$ theory and its reflection on practice. Procedia Social Science and Behavioural Sciences, 2, 4502-4506. https://doi.org/10.1016/j.sbspro.2010.03.720

Zakaria, E., Chin, L. C., \& Daud, M. Y. (2010). The effects of cooperative learning on students' mathematics achievement and attitude towards mathematics. Journal of social sciences, 6(2), 272-275. https:// doi.org/10.3844/jssp.2010.272.275

Zedan, R. (2010). New dimensions in classroom climate. Learning Environments Research, 13, 75-88. https://doi.org/10.1007/s10984-009-9068-5

Zins, J. E., Elias, M. J., Greenberg, M. T., \& Weissberg, R. P. (2000). Promoting social and emotional competence in children. In K. M. Minke, \& G. C. Bear (Eds.). Preventing school problems-promoting school success: Strategies and programs that work (pp. 71100). Bethesda, MD: NASP Publications. https://doi.org/10.1007/978-0-38779920-9_4 